\title{
Analysis of Levels and Content of Sludge Solid Waste in PDAM Bandarmasih
}

\author{
Eko Pramono $^{1 *}$ Taufik Hidayat ${ }^{2} \quad$ Bambang Eko Priatmadi $^{2} \quad$ Fatmawati $^{2}$ \\ 1.Graduate Program in Management of Resources Power Nature and the Environment, Lambung Mangkurat \\ University, Ahmad Yani Street, Banjarbaru 70614, South Kalimantan, Indonesia \\ 2.Program in Management of Resources Power Nature and the Environment, Lambung Mangkurat University, \\ Ahmad Yani Street, Banjarbaru 70614, Indonesia
}

\begin{abstract}
This study aims to analyze the level and content of the existing sludge in the solid waste sludge of PDAM Bandarmasih. The data used in the study is that the data lab to analyze the level of content that is contained in the waste solid sludge. While that becomes the object of research is a sample waste solid sludge taps Bandarmasih are contained in two places, namely the WWTP 1 in Jalan A. Yani Km.2 and WWTP 2 in Jalan Pramuka KM.6 Banjarmasin. The tools used to analysis the levels of waste solid sludge that is a tool of analysis Spectrophotometer Absorption Atomic (SSA) and Spectrophotometer UV-Vis. The parameters tested include measurement of sludge $\mathrm{pH}$, determination of water content and sample. Testing levels are needed that level of content of $\mathrm{Mg}, \mathrm{Cu}, \mathrm{Fe}, \mathrm{K}$, $\mathrm{P}$ and $\mathrm{Cd}$ using methods spectrophotometry, while to establish the total $\mathrm{N}$ using the method of Kjeldahl. Based on the results of the study showed that the concentration of Mg in WWTP 1 was $0.47 \%$ whileinWWTP 2 it was $0.38 \%$, for Fe content in WWTP $17.87 \%$ and WWTP $27.64 \%$. And for the content of K and P the level difference is not too significant, $\mathrm{K} 0.85 \%$ and $0.88 \%$, P $0.54 \%$ and $0.52 \%$, while for $\mathrm{N}$ levels are quite far, $1.12 \%$ and $1.35 \%$. Based on the results of the data analysis of content and the content of the mud have fill the value of the threshold limit of sludge that can be used.
\end{abstract}

Keywords: mud, PDAM, grade

DOI: $10.7176 / \mathrm{JESD} / 10-14-03$

Publication date:July $31^{\text {st }} 2020$

\section{Introduction}

The use of water clean largest especially in the area of urban Indonesia, namely to use the house stairs even up to $68 \%$ of total production water clean absorbed by the needs of the use of home stairs, especially in the city of Banjarmasin. Meanwhile, according to sources of local water company Drinking year 2012 states that $93 \%$ coverage using water clean is to the needs of home stairs. Regional Water Drinking (PDAM) into a manufacturer major producer of water clean for the needs of the basic (basic need) in the areas of urban, with the results alongside the production of activities are in the form of sludge (sludge). Needs water clean in the city of Banjarmasin which is always increased in line with the increasing rate of growth of the population, things have also led to an increase in sediment mud.

With regard to cost-effectiveness, labour planning always opts for the minimum amount of workers needed to deal with the daily operations, as well as the probable rate of disturbance (Lim et al. 2008). The workforce disturbance is often ascribed to absenteeism and turnover, which may result in considerable loss of productivity for any labour-intensive division (Easton \& Goodale 2002). Buffering with redundant skilled workers (Molleman \& Slomp 1999) or relief workers (Redding 2004) might be a direct solution to absenteeism; however, the rising labour cost must be justifiable due to the fact that underutilisation of labour during low demand seasons is considered a waste of resources. Absenteeism is the measure of unplanned absences from workplace due to some reasons like personal emergency, accident, illness, etc. Turnover occurs when an active worker resigns from the company of his own accord, thus leaving a vacant post until a replacement is found. If such disturbance has caused a large number of tasks become unattended and overdue, the company is then vulnerable to overtime cost, shrunk capacity and productivity, extra queuing time, lost business income, etc. In order to prevent these deteriorative effects, optimising the number of workers can be helpful. As a fundamental branch of knowledge in manufacturing business, workforce management will never fall behind the times. Therefore, it is worth an attempt to incorporate a novel methodology, such as HMS, into the state of the art of workforce sizing. The development of industry in Indonesia are relatively quite rapidly led to the increase in the amount of waste that is generated by industries such and if it is not able to be handled in a serious then it will cause problems in the environment. Many industries are only concerned with how to how to produce the results of the industry as much as possible without thinking about how the utilization of waste results processing industry such. The lack of knowledge about the processing and management of the utilization of waste industry is also becoming one of the factors inhibiting the management of the environment.

In essentially, a collection of sections of land were washed away carried away by the flow of water of the river is mud, where land that has a composition of four ingredients main are mutually related, namely materials 
minerals, materials of organic, air and water (Shelvi, 2012). In broad, material organic that is wasted or discarded are derived from the results of the activity of human as well as the nature of other can be referred to as waste. Based on the embodiment of the waste was itself divided into three, namely waste solid, waste liquid and waste gas. Of wastes that can cause pollution to the environment such as pollution of water, pollution of land and pollution of air. Things are going to happen if the wastes are not utilized in an optimal. One among the causes of pollution of the soil that is due to the use of fertilizer is excessive so that substances which are toxic to the surface of the ground is not able to decompose (Sucahyo et al, 2018).

Regional Water Drinking or taps is one among the institutions which produce waste a teach end of the process of production. There are two types of waste are produced by companies that are waste solid and waste liquid. Waste solid which becomes residual disposal activities of taps allowed to accumulate in one area, while to the waste liquid which is generated by the taps are usually discharged directly into water bodies such as rivers. Processing water clean are conducted by PDAM produce waste that is relatively large due to sedimentation of water raw (river)and some of the ingredients of organic more. Raw Organic are mostly in the form of metal weight with concentrations that vary also found in the waste liquid and waste solid results of activities of taps such as $\mathrm{Cd}$, $\mathrm{Pb}, \mathrm{Hg}, \mathrm{Cu}, \mathrm{Cr}$, and $\mathrm{Zn}$ not be decomposed by microorganisms (Hakim,2013).

Event purification and sterilization of water carried in the processing of water raw produce metals heavy that sometimes hazardous appropriate levels of abortion on the disposal of waste taps. In addition to the activities of industrial taps, while the activities of domestic and non-domestic were found to produce metal by weight is from waste industrial printing, industrial processing of material food, the process of fermentation, activity house stairs and more. And wastes that will pollute the whole area of the flow of the river. To determine the levels and content of any course that contained in the waste that it is necessary to do tests such as testing the levels of metals harmful or elements essential others who felt can be used to fertilize the soil and plants. Before ascertained to be disposed of or used, the waste that need to be analyzed first advance that if the waste it was decided to be discarded into the environment it is not going to harm the environment with some of the criteria specified so as not to pollute the environment.

Waste that is generated by the disposal of taps also in the form of mud either the solid or liquid with a number of which vary based on the amount of water standard that is used, turbidity (turbidity) and a capacity usage of materials to send in the process of flocculation (flocculation). In the summer rainy, the amount of production of sludge that is produced will increase as a result of turbidity which is caused by erosion and is one of the characteristics of the water surface. The level of turbidity mud into the base amount in the use of materials chemistry for handling the turbidity that, things have become indicative of the increase in production of sludge when the use of materials chemistry increased (Sucahyo et al, 2018).

Various impacts negatively are caused by the disposal of sludge taps experienced by communities around disposal. One among the impacts negatively on the disposal of sludge taps that their reactions are biochemical which cause are less at the time of reduction considering the use of sludge has not been optimal. In the run short, impacts negatively the perceived sometimes not effect on the environment around, while for the impact run length may interfere with the characteristics of natural soil. Load environment that increasingly large caused by the increasing amount of sludge that is produced and discharged into the environment without any treatment. By because it was so that the content of the sludge is not potentially pollute the environment it needed a way to reduce the content of metals heavy as well as how to use the mud is more effective.

\section{Research methods}

Research this requires materials that become objects that samples of waste sludge taps Bandarmasih and materials processing objects such as materials chemistry $\mathrm{NaOH}, \mathrm{HNO}_{3}, \mathrm{H}_{2} \mathrm{SO}_{4}, \mathrm{HCl}, \mathrm{HClO}_{4}$, acid ascorbic, $\mathrm{FeSO}_{4} .7 \mathrm{H}_{2} \mathrm{O}$, $\mathrm{Na}_{2} \mathrm{HPO}, \mathrm{CdCl}_{2} .2 \mathrm{H}_{2} \mathrm{O}, \mathrm{CuSO}_{4} .5 \mathrm{H}_{2} \mathrm{O}$, Conwayindicator, $\mathrm{MgSO}_{4} 6 \mathrm{H}_{2} \mathrm{O}, \mathrm{KCl}$, and distilled water. While for the equipment that is used in research is among others: $\mathrm{pH}$ meter, the tool filter waste, measuring glass, atrophy glass, neraca analytic, lash measuring, lash boiling, erlenmeyer, oven, tube reaction, the plate aluminium, eksikator, and measuring pipettes. As well as a tool of analysis Spectrophotometer Absorption Atomic (SSA) and Spectrophotometer UV-Vis.

Research is conducted at the Regional Water Company Drinking Bandarmasih Banjarmasin with 3 months starting from the collection of literature, collection of data, analysis of results and writing of the results of research. This sample was taken at the sediment mud reservoir in Bandarmasih PDAM. Samples were taken at the station Installation Treatment Water Waste Plant (WWTP) in 2 (two) locations were given the label WWTP 1 for the location of the disposal of waste taps Bandarmasin at Km 2 and WWTP 2 for the location of the disposal of waste taps Bandarmasih at Km 6. Taking samples in each WWTP do as much as 3 samples with an interval time of 8 hours each taking samples. The parameters tested include measurement of sludge $\mathrm{pH}$, determination of water content and sample preparation.

Analysis of the data used is the analysis of spectrophotometry and determination of total $\mathrm{N}$ with the method of Kjeldahl with explanation as follows. 
The analysis that is used there are several ways, namely by making a solution of a standard, making rows of standard elements such as $\mathrm{Fe}, \mathrm{Mg}, \mathrm{Cu}, \mathrm{K}$ and $\mathrm{Cd}$ by using analysis Spectrophotometer Absorption Atomic and measure the value of $\mathrm{P}$ by using analysis of Spectrophotometer. The stages of this analysis are making a standard solution, making a standard series of elements $\mathrm{Fe}, \mathrm{Mg}, \mathrm{Cu}, \mathrm{K}, \mathrm{P}$ and $\mathrm{Cd}$, measuring the concentration of $\mathrm{Fe}, \mathrm{Mg}$, $\mathrm{Cu}, \mathrm{K}$ and $\mathrm{Cd}$ using SSA and measuring the $\mathrm{P}$ value using a spectrophotometer.

Whereas to establish N Total by using the method of Kjeldahl used two analyses is the destruction of samples and distillation samples.

\section{Results and Discussion}

By-products from drinking water treatment systems can be in the form of PDAM sewage sludge sourced from surface water. Sedimentation of colloidal particles carried out quickly with the help of aluminum chemicals will result in sludge waste from the PDAM. Therefore, in the PDAM sewage sludge a very high aluminium content is found. And if these conditions are allowed to get higher and enter the body of water it will cause pollution.

Sampling of this study was carried out in two places namely WWTP Station for overflow disposal located on Jl. A. Yani Km 2 and WWTP Station 2 for waste disposal located at Jl. Scout Km 6 with the number of each three samples taken (interval of 8 hours for each sampling). For the average yield of $\mathrm{pH}$ value on sludge solid waste in WWTP 1 is 7.18 while in WWTP 2 is 7.15 . Based on a neutral pH value of 7.0 for liquid objects, it can be concluded that the $\mathrm{pH}$ of the effluent of sludge from PDAM Bandarmasih water treatment is in neutral condition.

Determination content of water samples of sewage sludge solid at the WWTP 1obtainedby53.49\%, while at the WWTP 2 obtained 47.88\%. Data are obtained based on the results of measurements were carried out respectively as much as 3 times the repetition of the results of the average as the data are. Based on the data from the manager of the disposal of waste solid sludge taps Bandarmasih, differences in the levels of water in samples of waste solid sludge at both stations disposal are due to the WWTP 1waste directly compacted after made shelter, things have led to the content of the mud a little, but the content of the water is a lot while at the WWTP 2 waste that is still mostly in the form of mud is only allowed to be accommodated in the pond disposal of waste then thickens as naturally as a result of the help of water rains that occur in bath shelters open. From the data it can be concluded that the system of processing performed on the two stations that provide the difference amount level of water in each sample. It's as submitted by Shelvi (2012) that the more viscous or more lots of mud due to water standard that is murky with the process of coagulation and flocculation will result in the volume of sludge to grow a lot by the levels of water.

In addition to the data the $\mathrm{pH}$ of waste solid sludge and levels of water, testing laboratories else to do that is to know the content of $\mathrm{Fe}, \mathrm{Mg}, \mathrm{K}, \mathrm{P}, \mathrm{Cu}$, and $\mathrm{Cd}$ using analysis spectrophotometer and analysis spectrophotometer absorption of atoms at each WWTP 1 and 2. Samples who conducted the testing at each WWTP is 3 testing with three replications with the number 9 samples at each WWTP. Of the 9 samples are taken the value of the average that will compare the results WWTP 1 and 2 as a whole. In testing this there are two results were obtained, namely units $\%$ and ppm.

The results of the analysis of the levels of Fe by using Spectrophotometer Absorption Atom can be seen in Table 1 below.

Table 1. Results of Fe Solid Waste Mud Analysis

\begin{tabular}{ccccc}
\hline Sample & 1 & 2 & 3 & Average \\
\hline WWTP 1 & 7.84 & 7.86 & 7.92 & 7.87 \\
\hline WWTP 2 & 7.65 & 7.65 & 7.64 & 7.64 \\
\hline
\end{tabular}

Information: WWTP $1=$ Waste disposal on Jl. A.Yani Km 2

WWTP 2 = Waste disposal on Jl. Scout Km 6

Based on the data table one can note that the content of the element Fe at the WWTP 1withan average of $7.87 \%$ over a lot compared to the WWTP 2 with an average of $7.64 \%$. At the WWTP 1 levels of Fe smallest is $7.80 \%$ and the largest is $7.95 \%$, while at the WWTP 2 levels of Fe smallest is $7.60 \%$ and the largest is $7.69 \%$. According to Revelation (2008) that the source of $\mathrm{Fe}$ in the water surface comes from the soil and leaching of minerals among others mineral hematite $\left(\mathrm{Fe}_{2} \mathrm{O}_{3}\right)$ and the mineral magnetite $\left(\mathrm{Fe}_{3} \mathrm{O}_{4}\right)$.

Iron is one among the elements of nutrient micro essential which has a role very important for plants because although necessary in a number of relatively little, but very large role in the metabolismin the plants, also can be damaging when found in a number of lots (Nurrahma et al, 2012). According Suryaningsih et al (2018) stated that the element iron is very needed by plants in the process of the formation of chlorophyll, but the number of the bit. The element iron also plays a role in the respiratory process of plants which is the most important physiological process in plants, besides that iron functions as an activator in the biochemical processes in plants, and forming several enzymes. The condition of the plants that corrosion and sheet leaves are yellowing is symptoms that due to shortage of the element iron. Iron can also be toxic to plants if found in certain amounts. In soil, the availability of iron ranges from 0.02 to $0.15 \%$ with the needs of a normal element of the iron in plant ranged from 0.04 to $2.5 \%$. The results of the analysis of the levels of Mg by using Spectrophotometer Absorption Atom can be seen in Table 
2 below.

Table 2. Mg Solid Waste Mud Analysis Results

\begin{tabular}{ccccc}
\hline Sample & 1 & 2 & 3 & Average \\
\hline WWTP 1 & 0.53 & 0.43 & 0.45 & 0.47 \\
\hline WWTP 2 & 0.43 & .36 & .34 & 0.38 \\
\hline
\end{tabular}

Based on Table 2 in the above can be known that the content of the elements $\mathrm{Mg}$ in the waste solid sludge WWTP 1 with grade average of $0.47 \%$ and in the IPAL 2 amounted to $0.38 \%$. The content of Mg lots produced from the soil and plants, as well as from the decomposition of waste domestic form of the rest of the vegetables are decomposed by water standard for traveling in along the river. Levels of the elements $\mathrm{Mg}$ in the WWTP 1 more substantial than the WWTP 2 due to the amount of water of the river that entered into the Disposal WWTP 1hasa number of volumes is large.

The element $\mathrm{Mg}$ is an element of nutrient medium (secondary), namely the elements nutrients needed in a number of medium, the role of $\mathrm{Mg}$ is a component of chlorophyll and cofactors in the plant. As part of the elements forming the chlorophyll, the elements $\mathrm{Mg}$ should be available in the levels of the adjusted because when a shortage of $\mathrm{Mg}$ available for the plant will lead to the symptoms - symptoms that appear on parts of leaves, especially on the leaves of old. Deficiency of $\mathrm{Mg}$ cause influence also on the growth of the seed, the plant that many has seeds should be noted fertilization with $\mathrm{MgSO}_{4}, \mathrm{MgCO}_{3}$ and $\mathrm{Mg}(\mathrm{OH})_{2}$ (Rizal, 2012).

The results of the analysis of the levels of $\mathrm{Cu}$ by using Spectrophotometer Absorption Atom can be seen in Table 3 below.

Table 3. Results of $\mathrm{Cu}$ Analysis of Solid Waste Mud

\begin{tabular}{ccccc}
\hline Sample & 1 & 2 & 3 & Average \\
\hline WWTP 1 & 101.2 & 98.6 & 99.3 & 99.7 \\
\hline WWTP 2 & 103,6 & 103.1 & 99.1 & 101.9
\end{tabular}

Based on Table 3 above shows that the Cu levels at WWTP station and WWTP 2 are not much different, with an average of $99.7 \mathrm{ppm}$ and $101.9 \mathrm{ppm}$. Comparison of the levels of the elements $\mathrm{Cu}$ at WWTP 2 which is higher slightly than the WWTP 1 due to the WWTP 2 processing is directly after the storage of waste so that minerals exist in the shelter experienced weathering. According Lahuddin (2007) that $\mathrm{Cu}$ derived from the results of weathering or leaching minerals contained in the rocks, copper is also derived from the waste materials that contain copper such as industrial dock ships, industrial processing of wood, and waste domestic. $\mathrm{Cu}$ is a micro nutrient that is needed by plants very little. In high concentrations, copper will be toxic, but in small amounts, copper is an essential nutrient for human and plant life (Adelia et al. 2013).

The results of the analysis of the content of K by using Spectrophotometer Absorption Atomic obtained the results as in Table 4 below.

Table 4. Results of Analysis of K Waste Solid Mud

\begin{tabular}{ccccc}
\hline Sample & 1 & 2 & 3 & Average \\
\hline WWTP 1 & 0.83 & 0.85 & 0.82 & 0.83 \\
\hline WWTP 2 & 0.88 & 0.75 & 0.82 & 0.82
\end{tabular}

Based on the data above shows that the levels of K in both stations WWTP only differ slightly, namely at the WWTP 1 the means amounted to $0.83 \%$, while at the WWTP 2 the means amounted to $0.82 \%$. By comparison are not significant it indicates that the sample of waste solid sludge on WWTP 1 and WWTP 2 is derived from the flow of the river are the same and are not there to treat advanced after made shelters waste. Elements $\mathrm{K}$ greatly determine the quantity and quality of the results of the plant for nutrients have a role important in them in: (1) process and translocation results of photosynthesis; (2) protein synthesis; and (3) increasing plant resistance to biotic stresses (pests/diseases) and abiotic (lack of water and iron or Fe poisoning), as well as improving physical conditions and chemical composition of agricultural products (Subandi, 2013).

The results of the analysis of $\mathrm{P}$ content by using a spectrophotometer can be seen in the following Table 5 .

Table 5. Results of Analysis P Waste Solid Mud

\begin{tabular}{ccccc}
\hline Sample & 1 & 2 & 3 & Average \\
\hline WWTP 1 & 0.54 & 0.52 & 0.55 & 0.54 \\
\hline WWTP 2 & 0.56 & 0.53 & 0.47 & 0.52
\end{tabular}

Based on the data above shows that the levels of P in samples of waste solid sludge WWTP 1 amounted to $0.54 \%$ and in the IPAL 2 amounted to $0.52 \%$. P content in the sludge WWTP 1isa high possibility due to water raw rich will be the content of phosphorus, many sources such as the availability of natural and twigs of trees that decompose in the water of the river. The element $\mathrm{P}$ is an element nutrient macro that is required in the number of lots. As we know the elements P plays an important in stimulating flowering and can improve the resistance to interference of pests and diseases on plants. One of the sources of phosphorus are of drift manure, sewage domestic, and mineral phosphates of nature. Phosphorus plays an important role in most enzyme reactions that depend on 
phosphorylase. By because phosphorus is part of the nucleus of cells, so it is important in the division of cells and also for the development of the network meristem (Zubaidah and Joey, 2007).

The results of the analysis of the levels of Cd by using Spectrophotometer Absorption Atom can be seen in Table 6 below.

Table 6. Results of Cd Solid Waste Mud Analysis

\begin{tabular}{ccccc}
\hline Sample & 1 & 2 & 3 & Average \\
\hline WWTP 1 & 13.7 & 14.2 & 14.8 & 14.2 \\
\hline WWTP 2 & 27.0 & 24.9 & 28.3 & 26.7 \\
\hline
\end{tabular}

Based on Table 6 above shows that the Cd level at WWTP sample station with an average of $14.2 \mathrm{ppm}$ and on WWTP 2 of $26.7 \mathrm{ppm}$. According Lahuddin (2007) inclusion of Cd in the waters of possibility due to the use of pesticides and fertilizer phosphate on the farm were carried away by the flow of the river that is used as a water standard for the treatment of water. According Liong et al (2009) stated that the accumulation of Cd if excessive can lead to the reduction of growth, and death of the plant, because $\mathrm{Cd}$ is one of a type of metal that is not required by an organism.

The results of the analysis of the content of $\mathrm{N}$ in total by using the method of Kjeldahl at stations sampled WWTP 1 amounted to $1.12 \%$, while the stations sampled WWTP 2obtainedamounted to $1.35 \%$. $\mathrm{N}$ is a macro nutrient that is needed by plants in large quantities. The role of $\mathrm{N}$ elements in plants is very important, namely to stimulate growth and increase the number and volume of fruit. According to Fahmi et al (2010) states that the addition of $\mathrm{N}$ through fertilization will stimulate root growth and increase plant root weight. The function of $\mathrm{N}$ in the soil that can improve the growth of vegetative plants, but if the excess $\mathrm{N}$ will occur symptoms that maturation of plants is inhibited, and can reduce power resistant plants against diseases.

Based on the results of the overall analysis of sludge solid waste samples at the two WWTPs in PDAM Bandarmasih that have been tested, the conclusions in Table 7 below are obtained.

Table 7. Data Analysis of Bandarmasih PDAM Mud Solid Waste

\begin{tabular}{lcrr}
\hline \multirow{2}{*}{ Parameter } & \multicolumn{3}{c}{ Test Results } \\
\cline { 2 - 4 } & Inlet Testing & \multicolumn{2}{c}{ Outlet Filtration } \\
\cline { 2 - 4 } & & WWTP 1 & WWTP 2 \\
\hline $\mathrm{pH}$ & $6-9_{(1)}$ & 7,18 & 7.15 \\
\hline $\mathrm{Water}$ content & $>35,6_{(2)}$ & 7.87 & 77.88 \\
\hline $\mathrm{Fe}$ & $<10_{(1)}$ & 0.47 & 7.64 \\
\hline $\mathrm{Mg}$ & $<0.64_{(3)}$ & 99.7 & 0.38 \\
\hline $\mathrm{Cu}$ & - & .83 & 101.9 \\
\hline $\mathrm{K}$ & $>0.48_{(3)}$ & 0.54 & .82 \\
\hline $\mathrm{P}$. & $>0.37_{(3)}$ & 14.2 & 0.52 \\
\hline $\mathrm{Cd}$ & - & 1.12 & 26.7 \\
\hline $\mathrm{N}$ total & $>1,0_{(2)}$ & & 1.35 \\
\hline
\end{tabular}

Note: $(-)=$ not analyzed

Sources: (1) Inlet Processing Waste (KEPMENLH No. Kep-58 / MENLH / 12/1995)

(2) Noor et al, 1996

(3) Komarayati and Ridwan, 2005

Based on the results of the analysis are, then made graphs on all parameters used to measure the value or level of each test parameter waste solid sludge that can be seen in Figure 2 below.

Figure 1. Graph of Bandarmasih PDAM Mud Solid Waste Analysis Chart

The graph above shows that the concentrations were highest in samples of waste solid sludge taps Bandarmasih namely the concentration of Fe of $7.87 \%$ at the station WWTP 1, and the concentration of Fe of $7.64 \%$ on the station WWTP 2. Large size of the content of Fe contained in the waste solid sludge PDAM Bandarmasih caused by the presence of soil, plants and also the process of decomposition of waste domestic from the rest of the vegetables and plants are decomposed by the water surface. Then the concentration of the smallest, namely the levels of Mg in the station WWTP 1 amounted to $0.47 \%$, while at the WWTP 2 amounted to $0.38 \%$. Levels of content that is shown on the graph in a tras become a reference for determining alternative processing waste solid sludge taps Bandarmasih which will be recommended. While for the content of the content of $\mathrm{Cu}$ and $\mathrm{Cd}$ in research is presented in units of ppm as in Table $8 . \mathrm{Cd}$ is one among metal weight that nature poisonous because $\mathrm{Cd}$ is not required by all organisms. According Lahuddin, (2007) the addition of $\mathrm{Cd}$ in water occurs through the use of fertilizer phosphate, fertilizers cage, and from the waste industry that uses the material burn coal are carried away by the water of rain that entered into the waters. 


\section{Conclusion}

The conclusions that can be drawn based on the results of the study are the levels and content of sludge in this study, namely $\mathrm{Fe}, \mathrm{Mg}, \mathrm{Cu}, \mathrm{K}, \mathrm{P}, \mathrm{Cd}$ and $\mathrm{N}$ which were analyzed using Atomic Absorption Spectrophotometry analysis and the Kjeldahl method with the average results at each WWTP namely levels of Fe (7.62 and 7.59)\%, $\mathrm{Mg}(0.49$ and 0.43$) \%, \mathrm{Cu}(88.33$ and 100.33$) \mathrm{ppm}, \mathrm{K}(0.85$ and 0.88$) \%, \mathrm{P}(0.54$ and 0.52$) \%, \mathrm{Cd}(13.80$ and 26.97$)$ ppm and $\mathrm{N}(1.12$ and 1.35$) \%$. Based on the results of the data analysis of content and the content of the mud have full fill the value of the thresh old limit of sludge that can be used back.

\section{Recommendation}

Based on the research that is conducted in PDAM Bandarmasih this, the author gives advice to do testing is further to determine the use of what are appropriate to do in the taps Bandarmasih to reduce the pollution that is generated by waste solid sludge. As well as the need to do the processing of the waste solid sludge that during this still has not been utilized.

\section{References}

Adella, P F., Koesriharti and Sunaryo. 2013. The Effect of Addition of Micro (Fe and $\mathrm{Cu}$ ) Nutrients in Liquid Relation Media and Liquid Cow Manure Against Comparison and Red Spinach (Amaranthus tricolor L.) Results with the Floating Raft Hydroponic System. Journal of Plant Production Vol.1 No.3. Malang: Brawijaya University. Page: 48-58.

Hakim, E. 2013. Up Take Analysis of Heavy Metal Content from Compost Sludge Water Treatment Plant by Plants. Bogor: Faculty of Agricultural Technology Bogor Agricultural University.

Liong, S., Alfian Noor, Paulina Taba and Hazirin Zubair. 2009. The Dynamics of Cadmium Accumulation in Ground Kale Plants (IpomoaereptansPoir). Indonesian Journal of Chimica Acta Vol.2 No.1. Makassar: Hasanuddin University.

Nurahma, A., Alimin and Wa Ode Rustiah. 2010. Analysis of Iron (Fe) Content in Moringa and Moringa oleifera Leaves Growing in Matajang Village, Two Boccoe, Bone Region. Makassar: UIN Alauddin Makassar and Makassar State University. Pages: 10-17.

Subandi. 2013. The Role and Management of Potassium Nutrients for Food Production in Indonesia. Journal of Agricultural Innovation Development Vol. 6 No. 1. Malang: Indonesian Legumes and Tubers Research Institute. Pages: 1-10.

Sucahyo, S.E., NitisAruming Firdaus and LuhurLintang. 2018. Management and Utilization of Mud Waste from the PDAM Cilacap. Journal Georafflesia Vol. 3 No. 2. Magelang: TirtaWiyataMagelang Technical Academy. Pages: 81-88.

Suryaningsih, Irwan Said and Nurdin Rahman. 2018. Analysis of Calcium (Ca) and Iron (Fe) Content in Water Kale (IpomeaeaquaticaForsk) and Land Kale (IpomeaereptanForsk) from Palu. Journal of Chemical Sciences Vol. 7 No. 3. Palu: Tadulako University. Pages: 130-135.

Zubaidah, Y. and Rafli Munir. 2007. Phosphorus Fertilization (P) Fertilization Activities in Rice Fields with Medium P Content. Journal of Solum (Land) Vol. 4 No. 1. West Sumatera: Indonesian Agricultural Technology Research Institute. Pages: 1-4. 